\title{
Rentowność portfeli inwestycyjnych zbudowanych na bazie relacji częściowego porządku
}

\section{Streszczenie}

W artykule przedstawiono porównanie efektywności inwestycji w portfele inwestycyjne w warunkach dozwolonej i zabronionej krótkiej sprzedaży z zastosowaniem relacji ograniczonej ceny ryzyka (OCR). Relacja OCR w zadanym zbiorze osiemnastu akcji ustala częściowy porządek zgodny z porządkiem całkowitym zadanym przez współczynnik efektywności Sharpe'a $(W S)$. Wynika on z zależności: jeżeli akcja $A$ jest w relacji OCR z akcją $B$, to $W S_{A}<W S_{B}$. Z perspektywy współczynnika Sharpe’a w danym łańcuchu relacji OCR element maksymalny jest elementem najbardziej efektywnym.

$\mathrm{Z}$ uzyskanych w ten sposób elementów maksymalnych utworzono portfele: $P_{\text {min }}$ (portfel minimalnego ryzyka), $P$ (portfel efektywny o zadanej stopie zwrotu $5 \%$ ) oraz portfel $P_{W S}$ (portfel o udziałach zgodnych z wartościami współczynnika $W S$ ). Portfele te zostały porównane z portfelami utworzonymi ze wszystkich badanych inwestycji według tych samych reguł co portfele $P, P_{\text {min }}, P_{W S^{*}}$. Okazuje się, że w kolejnych okresach ustalonego horyzontu czasowego rentowność portfeli utworzonych z elementów maksymalnych była wyższa niż rentowność portfeli utworzonych ze wszystkich inwestycji bazowych.

Słowa kluczowe: krzywa Markowitza, portfel efektywny, strategia inwestycyjna, krótka sprzedaż, elementy maksymalne relacji częściowego porządku. 


\section{Wprowadzenie}

Celem opracowania ${ }^{1}$ było porównanie efektywności inwestycji portfelowych złożonych z wybranych aktywów Giełdy Papierów Wartościowych w Warszawie na gruncie klasycznej teorii portfelowej Markowitza. W zadanym przez autorów okresie aktywa te wchodziły w skład indeksu WIG20. Efektywność utworzonych portfeli porównano z notowaniami wskaźników WIG i WIG20 w warunkach dozwolonej (KSD) i zabronionej (KSZ) krótkiej sprzedaży ze szczególnym uwzględnieniem relacji ograniczonej ceny ryzyka OCR [Guzik 2002]. Relację OCR wprowadzono na bazie porządku całkowitego zadanego przez współczynnik efektywności inwestycji Sharpe'a (WS). Relacja OCR w zadanym zbiorze aktywów wprowadza, w sensie matematycznym, porządek częściowy. Jest zatem relacją zwrotną, przechodnią i antysymetryczną.

Pojedyncze aktywa, składniki portfela $P$, będą nazywane inwestycjami bazowymi. W analizie uwzględniono walor wolny od ryzyka $F$, o rentowności $r_{f}$. Aktyw $F$ nie będzie składnikiem omawianych portfeli. Nie zawęża to w żaden sposób rozważań, gdyż portfel $P_{0}$ o zadanych parametrach można potraktować jako zestawienie dwóch składników: $P$ (aktywów ryzykownych) oraz $F$ przy odpowiednich udziałach. Przyjęto przy tym klasyczne założenia o rynku kapitałowym, takie jak: nieskończoną podzielność aktywów i brak kosztów transakcji.

Przyjmujemy, że każda inwestycja bazowa oraz portfelowa na rynku kapitałowym charakteryzowana jest przez dwa parametry: oczekiwaną stopę zwrotu inwestycji $E r$ oraz odchylenie standardowe $s$ oczekiwanej stopy zwrotu będące miarą ryzyka. Graficznie inwestycję przedstawiono jako punkt w układzie współrzędnych $(s, E r)$. Ponieważ w analizie nie będą uwzględniane inne charakterystyki ${ }^{2}$, dlatego z dwóch inwestycji (portfeli) o tych samych wartościach $E r$ oraz $s$ wzięto pod uwagę tę o mniejszej liczbie składników. Im mniejsza liczba składników w portfelu, tym łatwiejsze zarządzanie takim portfelem, zwłaszcza dla indywidualnego inwestora.

Podane niżej formuły i zależności [Guzik i Smaga 2008, Piasecki 2005] wykorzystano w dalszej części pracy. Przyjmujemy, że portfel inwestycyjny konstruujemy z dowolnego podzbioru zbioru $N$ inwestycji bazowych $A_{i}$, gdzie $i \in\{1, \ldots, N\}$. W ten sposób można utworzyć nieskończenie wiele portfeli, w zależ-

${ }^{1}$ Niniejszy artykuł stanowi wynik realizacji projektu badawczego Strategia inwestycyjna ograniczająca liczbę akcji w portfelu $w$ odniesieniu do krzywej Markowitza, nr 111/ KM/1/2011/S/590, Uniwersytet Ekonomiczny w Krakowie.

2 Oprócz wspomnianych charakterystyk pojedynczą lub portfelową inwestycję można charakteryzować poprzez asymetrię oraz kurtozę rozkładu. Pomocne w wyborze inwestycji mogą być również takie wielkości, jak: kapitalizacja i często związana z nią płynność (wielkość obrotu) jak również wskaźniki finansowe emitenta akcji (analiza fundamentalna). 
ności od udziałów poszczególnych składników, które charakteryzowane są przez układ:

$$
\left\{\begin{array}{c}
E r_{P}=\sum_{i=1}^{N} x_{i} E r_{i} \\
s_{P}^{2}=\sum_{i=1}^{N} \sum_{j}^{N} x_{i} x_{j} s_{i} s_{j} r_{i j}=\sum_{i=1}^{N} \sum_{j=1}^{N} x_{i} x_{j} \operatorname{cov}_{i j} \\
\sum_{i=1}^{N} x_{i}=1, \\
\underset{i \in\{1, \ldots, N\}}{\forall} x_{i} \geq 0,
\end{array}\right.
$$

gdzie:

$E r_{i}, E r_{P}$ - wartość oczekiwana $i$-tego składnika portfela oraz portfela $P$, $s_{i}, s_{P}$ - odchylenie standardowe $i$-tego składnika portfela oraz portfela $P$,

$x_{i}$ - udział $i$-tego składnika w portfelu,

$r_{i j}$ - współczynnik korelacji między $i$-tym a $j$-tym aktywem,

$\operatorname{cov}_{i j}$ - kowariancja między $i$-tym a $j$-tym składnikiem portfela.

Układy warunków (1) -(3) oraz (1) -(4) opisują zbiór możliwości inwestycyjnych odpowiednio w wariantach KSD oraz KSZ, przy czym kowariancję $\operatorname{cov}_{i j}$ określamy wzorem $\operatorname{cov}_{i j}=s_{i} s_{j} r_{i j}$.

Zależności (1)-(3) można zapisać w postaci macierzowej:

$$
\begin{aligned}
& E r_{P}=X^{T} E, \\
& s_{P}^{2}=X^{T} K X, \\
& {[1]^{T} X=1,}
\end{aligned}
$$

gdzie:

$$
\begin{aligned}
& X^{T}=\left[\begin{array}{llll}
x_{1} & x_{2} & \ldots & x_{N}
\end{array}\right], \\
& E^{T}=\left[\begin{array}{lll}
E r_{1} & E r_{2} \ldots E r_{N}
\end{array}\right], \\
& {[1]^{T}=\left[\begin{array}{lll}
1 & 1 & \ldots
\end{array}\right],} \\
& K=\left[\begin{array}{ccc}
s_{1}^{2} & s_{1} s_{2} r_{12} & s_{1} s_{3} r_{13} \ldots \ldots . s_{1} s_{N} r_{1 N} \\
s_{2} s_{1} r_{21} & s_{2}^{2} & s_{2} s_{3} r_{23} \ldots \ldots . s_{2} s_{N} r_{2 N} \\
\ldots \ldots & \ldots \ldots . & \ldots \ldots \ldots \ldots \ldots \ldots \ldots \ldots . . \\
s_{N} s_{1} r_{N 1} & s_{N} s_{2} r_{N 2} & s_{N} s_{3} r_{N 3} \ldots \ldots \ldots s_{N}^{2} \ldots
\end{array}\right]=\left[\operatorname{cov}_{i j}\right] .
\end{aligned}
$$

Istotnym zagadnieniem teorii portfelowej jest ustalenie udziałów inwestycji bazowych portfeli efektywnych, co zwykle sprowadza się do minimalizacji 
funkcji wariancji (2) przy warunkach (1) i (3) lub warunkach (1), (3) i (4) odpowiednio w wariantach KSD i KSZ. Portfele te leżą na krzywej Markowitza. Na podstawie metody mnożników Lagrange'a w wariancie KSD można podać jej postać analityczną (5):

$$
s_{P}^{2}=\frac{C}{D} E r_{p}^{2}-\frac{2 B}{D} E r_{p}+\frac{A}{D},
$$

przy czym

$$
\begin{aligned}
& A=E^{T} K^{-1} E, \\
& B=[1]^{T} K^{-1} E, \\
& C=[1]^{T} K^{-1}[1], \\
& D=A C-B^{2} .
\end{aligned}
$$

Z postaci wzoru (5) wynika, że krzywa Markowitza w układzie $\left(s^{2}, E r\right)$ jest parabolą, natomiast w układzie $(s, E r)$ jest hiperbolą.

Na podstawie równania (5), dla zadanej wartości oczekiwanej stopy zwrotu $E r_{0}$, wyznaczamy minimalną wariancję portfela:

$$
s_{\min }^{2}=\frac{C}{D} E r_{0}^{2}-\frac{2 B}{D} E r_{0}+\frac{A}{D} .
$$

Udziały inwestycji bazowych w portfelu efektywnym przy zadanej wartości oczekiwanej $E r_{0}$ wyznaczamy wzorem:

$$
X=\frac{1}{D}\left(A K^{-1}[1]-B K^{-1} E\right)+\frac{1}{D}\left(C K^{-1} E-B K^{-1}[1]\right) E r_{0} .
$$

Wyznaczenie udziałów portfela leżącego na krzywej Markowitza w wariancie KSZ jest zagadnieniem programowania kwadratowego. Odpowiednie obliczenia zostaną wykonane za pomocą modułu solver programu Excel.

\section{Relacja częściowego porządku}

Inwestor, konstruując portfel o jak najmniejszym ryzyku i jak najwyższej stopie zwrotu, powinien, zgodnie z teoria portfelową, uwzględnić w swoim portfelu jak największą liczbę akcji. Zbyt duża liczba akcji w portfelu może jednak spowodować utrudnienia w zarządzaniu. Ponadto jak wskazują badania zwiększanie liczby składników portfela powyżej 20-30 nie powoduje już znacznego obniżenia ryzyka (zob. [Guzik i Smaga 2013, s. 83]).

Inwestor z dostępnego zestawu akcji powinien zatem wybrać pewną liczbę najlepszych akcji. W tym celu należy uporządkować akcje zgodnie z ustalonym 
kryterium. Takie uporządkowanie może wynikać np. z rosnącej oczekiwanej stopy zwrotu lub malejącego ryzyka. Połączenie tych charakterystyk we współczynnikach efektywności inwestycji np. Sharpe'a, Treynora i Jensena pozwala uporządkować akcje od najmniej do najbardziej efektywnej.

W dalszej części opracowania weźmiemy pod uwagę porządek w wybranej grupie inwestycji bazowych, który został ustalony na podstawie współczynnika Sharpe'a $W S_{A}$, który dla akcji $A$ dany jest wzorem:

$$
W S_{A}=\frac{E r_{A}-r_{f}}{S_{A}}
$$

gdzie:

$W S_{A}$ - współczynnik Sharpe’a akcji $A$,

$\mathrm{Er}_{A}$ i $s_{A}$ - oczekiwana stopa zwrotu i ryzyko akcji $A$,

$r_{f}$ - stopa wolna od ryzyka.

Wyższa wartość WS oznacza inwestycję bardziej korzystną. Zatem ta akcja jest korzystniejsza, która daje wyższą premię za tę samą jednostkę ryzyka, gdzie premią za ryzyko jest nazywana różnica $E r_{A}-r_{f}$, a iloraz $\frac{E r_{A}-r_{f}}{s_{A}}$ jest określany jako cena ryzyka.

W skład inwestycji portfelowej wchodziłyby zatem najlepsze akcje z rankingu ustalonego na podstawie $W S$. W doborze składników portfela należy uwzględnić ich wzajemną korelację będącą kluczowym elementem przy obniżaniu ryzyka portfelowego. Właśnie ten aspekt znajdzie odbicie w definiowanej relacji częściowego porządku.

Na wstępie zakładamy porządek zadany w zbiorze akcji przez WS. W tym miejscu zostanie przedstawiona definicja [Guzik 2002] oraz podstawowe fakty związane z relacją OCR, przy czym ich dowody pominiemy, w szczególności dowód, że relacja ta jest relacją częściowego porządku.

Definicja relacji OCR. Jeżeli współczynnik Sharp’a akcji $A$ jest mniejszy od współczynnika Sharpe'a akcji $B$, to akcja $A$ spełnia z akcją $B$ warunek ograniczonej ceny ryzyka OCR ( $A$ OCR $B$ ) wtedy i tylko wtedy, gdy dla każdego portfela $P$ zestawionego z akcji $A$ i $B$ spełniony jest warunek:

$$
\frac{E r_{A}-r_{f}}{s_{A}} \leq \frac{E r_{P}-r_{f}}{s_{P}} \leq \frac{E r_{B}-r_{f}}{s_{B}}
$$

$\mathrm{Z}$ tak postawionej definicji wynika, że jest ona zgodna z porządkiem całkowitym zadanym przez współczynnik Sharpe’a, tzn. zachodzi implikacja:

$$
A \text { OCR } B \Rightarrow W S_{A} \leq W S_{B} .
$$


Oznacza to, że warunkiem koniecznym zaistnienia relacji OCR między akcjami $A$ oraz $B$ jest nierówność $W S_{A} \leq W S_{B}$.

Ilustrację graficzną relacji OCR przedstawia rys. 1 . Z jej definicji wynika, że wraz ze wzrostem wartości oczekiwanej stopy zwrotu portfela $P$ rośnie również cena ryzyka tego portfela, co oznacza coraz wyższą wartość ułamka $\frac{E r_{P}-r_{f}}{S_{P}}$. Brak relacji oznacza, że część łuku $B A$ (łuk $B A^{\prime}$ ) znajdzie się ponad prostą $F B$. Jeżeli relacja nie zachodzi, to przy danym poziomie ryzyka możemy uzyskać wyższą stopę zwrotu niż w sytuacji, gdy relacja zachodzi.

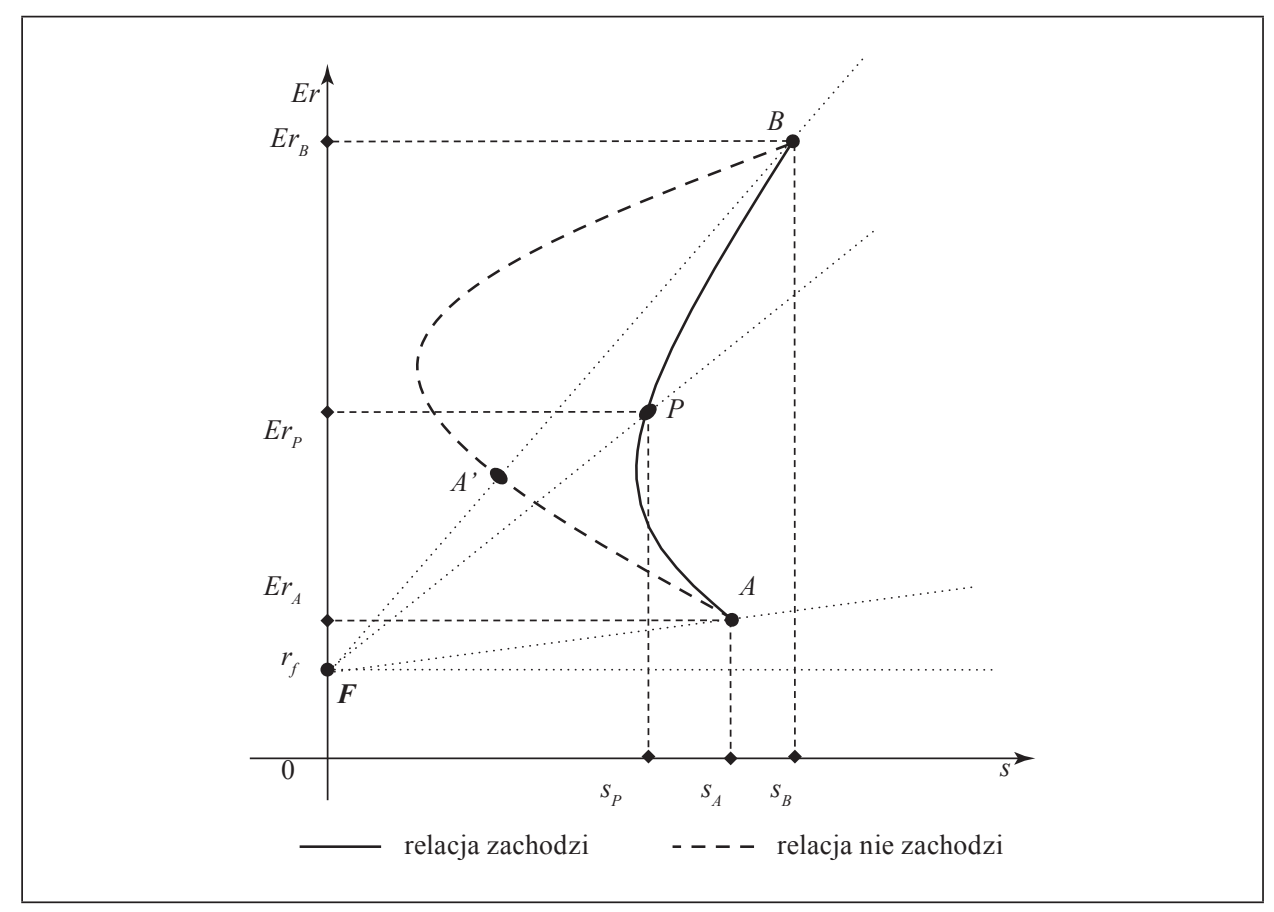

Rys. 1. Relacja ograniczonej ceny ryzyka OCR Źródło: opracowanie własne.

Ponadto im niższa wartość współczynnika korelacji tym mniejsza szansa na to, że relacja będzie zachodzić. Wynika to z kształtu zbioru możliwości inwestycyjnych dla dwóch akcji. Zatem występuje silny związek między wartością współczynnika korelacji a faktem zaistnienia bądź niezaistnienia relacji OCR. Zależność tę pokazuje poniższy warunek.

Warunek równoważny relacji OCR. Jeżeli $0<W S_{A}<W S_{B}$ akcja $A$ spełnia $\mathrm{z}$ akcją $B$ relację ograniczonej ceny ryzyka wtedy i tylko wtedy, gdy współ- 
czynnik korelacji $r_{A B}$ jest nie mniejszy od ilorazu współczynnika Sharpe’a akcji $A$ do współczynnika Sharpe’a akcji $B$, tzn.

$$
r_{A B} \geq \frac{W S_{A}}{W S_{B}}
$$

Sprawdzenie czy dwie akcje pozostają ze sobą w relacji OCR za pomocą formuły (9) będzie bardziej praktyczne niż wprost z definicji.

Ponieważ relacja OCR jest zwrotna, symetryczna i przechodnia jest zatem relacją częściowego porządku³. Relacja ta dzieli zatem wyjściowy zbiór akcji na łańcuchy zależności, wśród których będzie można wyróżnić elementy minimalne i maksymalne ${ }^{4}$. W każdym łańcuchu elementem maksymalnym będzie akcja mająca najwyższy WS ze wszystkich będących w danym łańcuchu. Dla danego elementu maksymalnego nie istnieje akcja o wyższym WS będąca z nim w relacji. Ponieważ elementy maksymalne nie są ze sobą w relacji, to współczynniki korelacji między nimi są relatywnie mniejsze (w odniesieniu do sytuacji gdyby relacja zachodziła). Jednocześnie akcje te mają wysokie współczynniki Sharpe’a, więc są atrakcyjnymi składnikami portfela. Jeśli parametry takiego portfela będą dla nas satysfakcjonujące, to dodatkową korzyścią będzie mniejsza liczba inwestycji bazowych w stosunku do portfela złożonego z wszystkich analizowanych akcji.

\section{Opis i założenia strategii inwestycyjnej}

Celem realizowanej strategii będzie porównanie rentowności zaproponowanych portfeli inwestycyjnych utworzonych na podstawie całego zbioru możliwości inwestycyjnych z portfelami utworzonymi w analogiczny sposób, ale złożonymi z elementów maksymalnych relacji OCR. Uwzględniamy warianty KSD i KSZ w strategii statycznej (ustalone udziały w portfelu nie zmieniają się w trakcie trwania inwestycji) oraz dynamicznej (modyfikacja udziałów składników portfela w kolejnych okresach trwania inwestycji). W kolejnych okresach horyzontu inwestycyjnego portfele te będziemy porównywać ze sobą oraz ze wskaźnikami WIG i WIG20 pod względem zrealizowanych stóp zwrotu.

${ }^{3}$ Dowód (przedstawiony w pracy [Guzik 2002]) wymaga m.in. założeń modelu wskaźnikowego Sharpe’a o nieskorelowaniu składników resztowych w modelu wskaźnikowym między sobą ani ze wskaźnikiem modelu oraz, że wartość oczekiwana wskaźników resztowych poszczególnych akcji jest równa zero. Ponieważ te założenia nie zawsze są spełnione, to w praktyce własność przechodniości w pewnych przypadkach nie jest spełniona, co może zaburzać strukturę relacyjną w zbiorze akcji.

${ }^{4}$ Elementów minimalnych i maksymalnych dla danej relacji częściowego może być wiele w odróżnieniu od relacji porządku całkowitego, dla którego mamy tylko jeden element minimalny (wartość najmniejszą) i jeden element maksymalny (wartość największą). 
Badania empiryczne pozwolą znaleźć odpowiedź czy ograniczenie zbioru możliwości inwestycyjnych zaproponowane w opracowaniu w znaczący sposób ogranicza zyski inwestora (oczekiwana stopa zwrotu) oraz te zrealizowane. Przyjmujemy miesięczny okres wyznaczania stóp zwrotu. Na podstawie danych historycznych ${ }^{5}$ (notowania cen) wyznaczamy estymator wartości oczekiwanej (średnia arytmetyczna) oraz odchylenia standardowego. W niniejszej pracy przyjęto, że będzie to osiemnaście miesięcznych obserwacji. Horyzont inwestycyjny ustalamy na 10 miesięcy.

Z ustalonej grupy akcji (głównie z indeksu WIG20) do wyjściowego zbioru inwestycji bazowych będziemy zaliczać akcje, dla których WS będzie dodatni. W związku z tym pierwotnie wybrany zbiór może ulec zmniejszeniu. Również w kolejnych okresach horyzontu inwestycyjnego zbiór inwestycji bazowych może pod tym względem ulegać modyfikacjom.

Na podstawie $N$ inwestycji bazowych ustalamy zbiór możliwości inwestycyjnych i jego brzeg, którego równanie przedstawia wzór (5) w wariancie KSD. W trakcie badań będą analizowane trzy rodzaje portfeli: $P_{\min }$ - portfel minimalnego ryzyka, $P$ - portfel o zadanej stopie zwrotu (przyjęto 5\%) oraz $P_{W S}-$ portfel, którego udziały wyznaczamy proporcjonalnie do wartości współczynnika Sharpe'a. Portfele $P_{\min }$ i $P$ należą do krzywej Markowitza i są efektywne, natomiast portfel $P_{W S}$ znajdzie się wewnątrz zbioru możliwości inwestycyjnych.

Udziały $x_{i}$ portfela $P_{W S}$ wyznaczone zgodnie z klasyczną regułą inwestowania, według której wyższy udział w portfelu przyznajemy aktywom o wyższej stopie zwrotu i niższym ryzyku dla $i \in\{1,2, \ldots, N\}$ dane są wzorami:

$$
x_{i}=\frac{W_{i}}{\sum_{i=1}^{N} W_{i}},
$$

gdzie $W_{i}$ są nieujemnymi współczynnikami Sharpe’a kolejnych akcji (tylko wariant KSZ). Pozostałe charakterystyki portfel $P_{W S}$ otrzymujemy ze wzorów (1) i (2).

Charakterystyki portfeli $P_{\min }$ i $P$ oraz udziały inwestycji bazowych w wariancie KSD wyznaczamy na podstawie wzorów (1) oraz (5) i (6) a w wariancie KSZ za pomocą modułu solver. Przykładowe położenie portfeli $P_{\text {min }}$ i $P$ oraz $P_{W S}$ przedstawia rys. 2.

${ }^{5}$ Uwagi na temat długości okresu oraz liczby danych historycznych przedstawiono m.in. w pracy [Jajuga i Jajuga 1998, s. 97-98]. Ze względu na stabilność średniej arytmetycznej liczba danych wziętych pod uwagę nie powinna być zbyt mała. Z kolei na wartości przyszłych stóp zwrotu największy wpływ będą miały wartości bieżące lub z niedalekiej przeszłości, stąd liczba danych nie powinna być zbyt duża. 


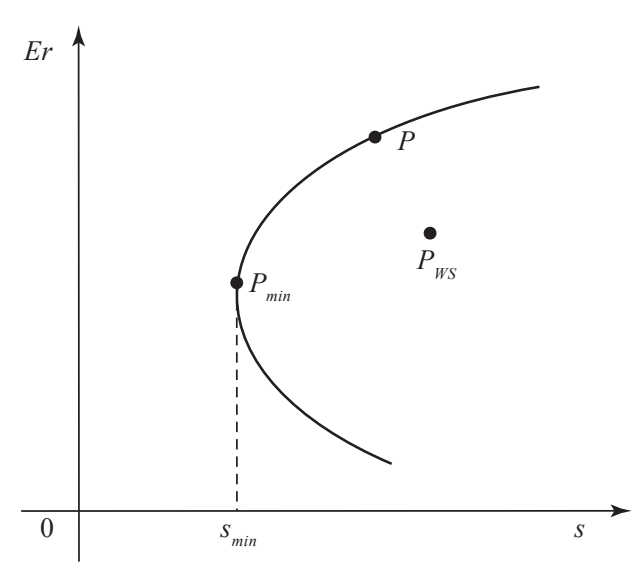

Rys. 2. Położenie portfeli: $P_{\text {min }}, P_{W S}, P$ krzywej Markowitza Źródło: opracowanie własne.

Przyjmujemy, że wartość początkowa, którą przeznaczamy na zakup poszczególnych akcji, każdego portfela wynosi $K_{P}^{0}=100$ jednostek pieniężnych. W pierwszej (statycznej) strategii inwestycyjnej przez 10 kolejnych okresów (miesięcy) nie zmieniamy udziałów składników portfela inwestycyjnego. W każdym okresie wyznaczamy wartość tego portfela, uwzględniając zrealizowane stopy zwrotu $N$ inwestycji bazowych wchodzących w skład portfela. Wartość portfela w kolejnych okresach prognozy wyraża się zatem wzorem:

$$
K_{P}^{i}=\sum_{k=1}^{N} K_{P}^{i-1} x_{k}\left(1+r_{k}^{i}\right)
$$

gdzie:

$i \in\{1,2, \ldots, 10\}$,

$K_{P}^{i}$ - wartość portfela $P$ na koniec okresu $i$,

$x_{k}$ - udział $k$-tej inwestycji bazowej w portfelu $P$, gdzie $k \in\{1,2, \ldots, N\}$,

$r_{k}^{i}$-stopa zwrotu z $k$-tej inwestycji bazowej na koniec okresu $i$.

Występująca we wzorze (11) stopa zwrotu $r_{k}^{i}$ jest realizacją zmiennej losowej $r_{k}$ w okresie $i$.

W drugiej (dynamicznej) strategii inwestycyjnej po każdym z 10 okresów horyzontu inwestycyjnego modyfikujemy zbiór możliwości inwestycyjnych. Modyfikacja wiąże się z tym, że wartość oczekiwana stopy zwrotu danej inwestycji bazowej liczona na okres $i=2$ (a w konsekwencji odchylenie standardowe) wyznaczamy na podstawie danych historycznych obejmujących poprzed- 
nich 18 kolejnych okresów z uwzględnieniem okresu $i=1$. Taką procedurę (przesunięcie danych o jeden miesiąc) powtarzamy w kolejnych okresach aż do ostatniego $i=10$. Przyjęcie takiej strategii oznacza, że w kolejnych okresach udziały poszczególnych składników portfela zmienią się. Zmiana udziałów wynikać będzie ze zmienionych wartości oczekiwanych stóp zwrotu inwestycji bazowych. Dodatkowo może się okazać, że wyznaczony dla niektórych inwestycji bazowych nowy WS jest ujemny, co zgodnie z przyjętą strategią oznacza odrzucenie takiej inwestycji w kolejnym okresie i wpływa na zmianę udziałów pozostałych składników. Wzór (11) przyjmuje zatem postać:

$$
K_{P}^{i}=\sum_{k=1}^{\tilde{N}} K_{P}^{i-1} x_{k}^{i-1}\left(1+r_{k}^{i}\right)
$$

gdzie:

$\tilde{N}$ - liczba elementów zbioru inwestycji bazowych, przy czym $\tilde{N} \leq N$,

$x_{k}^{i-1}-$ udział $k$-tej inwestycji bazowej w portfelu $P$, na koniec okresu $i$.

Jeżeli we wzorze (12) podstawimy $i=1$, to wtedy $x_{k}^{0}$ oznacza początkowy udział $k$-tej inwestycji bazowej w portfelu $P$, ustalony na podstawie danych historycznych z pierwszych 18 okresów miesięcznych. Otrzymane wyniki porównamy z portfelami odzwierciedlającymi koniunkturę na rynku, czyli z portfelami WIG20 i WIG.

W dalszej kolejności na podstawie zależności (9) ustalamy strukturę relacyjną w zbiorze $Z_{N}$. Strategia inwestycyjna zastosowana do zbioru $N$ inwestycji bazowych $\left(Z_{N}\right)$ zostanie w analogiczny sposób powtórzona w jego podzbiorze, w skład którego będą wchodzić elementy maksymalne $\left(Z_{\max }\right)$ relacji OCR. Elementy maksymalne łańcuchów relacji OCR utworzą nowy zbiór inwestycji bazowych, z których utworzymy nowe portfele $P_{\min }$ i $P$ oraz $P_{W S^{*}}$

\section{Weryfikacja empiryczna}

W badaniach empirycznych uwzględniono akcje z indeksu WIG20, które od 1 stycznia 2009 r. do 30 czerwca 2010 r. znajdowały się w tym indeksie lub były do niego dołączone ewentualnie z niego usunięte. W rezultacie wraz z kilkoma akcjami indeksu WIG40 w badaniach uwzględniono akcje 25 spółek. Wybrane akcje to: Agora, Assecopol, Bioton, BRE, BZWBK, Cersanit, Emperia, Eurocash, Getin, GTC, INGBSK, KGHM, LOTOS, LPP, Millenium, Netia, PBG, Pekao, PKN ORLEN, PKOBP, POLIMEXMS, Polnord, Synthos, Świecie, TVN.

Na podstawie okresu 1.01.2009-30.06.2010 (18 miesięcznych obserwacji), dalej zwanym okresem I, wyznaczono wartości estymatorów charakterystyk badanych akcji i utworzono odpowiednie portfele. W kolejnych miesięcznych 
okresach (do 30.06.2011) postępowano zgodnie z omówioną w poprzednim punkcie procedurą, oceniając analizowane portfele pod kątem zrealizowanej stopy zwrotu. Na przykładzie okresu I przedstawimy procedurę powtarzaną w kolejnych miesiącach.

$\mathrm{Z}$ analizowanej grupy akcji uwzględniamy te, które charakteryzują się dodatnim $W S$ w badanym okresie. Osiemnaście akcji (zbiór $Z_{18}$ ) spełniających powyższy warunek przedstawia tabela 1.

Tabela 1. Akcje uszeregowane zgodnie z rosnącym $W S$ w okresie I

\begin{tabular}{|c|l|c|c|l|c|c|l|c|}
\hline Lp. & Nazwa spółki & WA & Lp. & Nazwa spółki & WA & Lp. & Nazwa spółki & WA \\
\hline 1 & PKOBP & 0,0474 & 7 & Millenium & 0,1867 & 13 & Świecie & 0,3097 \\
\hline 2 & TVN & 0,0937 & 8 & LPP & 0,2199 & 14 & Lotos & 0,3148 \\
\hline 3 & Pekao & 0,1004 & 9 & BZWBK & 0,2258 & 15 & Eurocash & 0,4314 \\
\hline 4 & BRE & 0,1008 & 10 & INGBSK & 0,2370 & 16 & KGHM & 0,5068 \\
\hline 5 & Agora & 0,1606 & 11 & Getin & 0,2610 & 17 & Netia & 0,5239 \\
\hline 6 & PKN Orlen & 0,1690 & 12 & Emperia & 0,2627 & 18 & Synthos & 0,6079 \\
\hline
\end{tabular}

Źródło: dane pobrane z serwisu internetowego www.gpw.pl oraz obliczenia własne.

W tak uporządkowanym zbiorze akcji wprowadzamy relację ograniczonej ceny ryzyka OCR. Obliczenia wykonujemy na podstawie wzoru (9) dla $r_{f}=0,003599^{6}$. Gdy relacja między akcjami znajdującymi się w danym wierszu i kolumnie zachodzi, to fakt ten oznaczamy symbolem , , " w przeciwnym razie „-". W ten sposób otrzymujemy tabelę relacji w okresie I.

Wiersze tabeli 2, w których znajdują się wyłącznie symbole ,--", wyznaczają elementy maksymalne relacji $\left(Z_{\max }\right)$. W okresie I jest 7 takich akcji. Są to: LPP, Emperia, Świecie, Eurocash, KGHM, Netia, Synthos. Następnie wyznaczamy krzywe Markowitza dla zbioru $Z_{18}$ oraz $Z_{\max }$ w wariantach KSD i KSZ, dane poniższymi równaniami. W kolejnym kroku wyznaczone zostały charakterystyki portfeli $P_{\min }$ i $P$ oraz $P_{W S}$ w okresie I, co przedstawia tabela 3.

$$
\begin{array}{ll}
Z_{18}: & s_{P}^{2}=0,0330 E r_{p}^{2}-0,0075 E r_{p}+0,0004, \\
Z_{\max }: & s_{P}^{2}=5,5852 E r_{p}^{2}-0,4475 E r_{p}+0,0100 .
\end{array}
$$

Zauważamy, że portfele $P_{\min }$ i $P$ mają takie same charakterystyki w wariantach KSD i KSZ, niezależnie od tego czy są wyznaczone na podstawie całego zbioru możliwości inwestycyjnych, czy jego podzbioru (elementów maksymalnych relacji OCR). Położenie portfeli $P_{\min }$ i $P$ oraz $P_{W S}$ utworzonych ze zbioru

${ }^{6}$ Wartość ustalona na podstawie średniej rentowności rocznych bonów skarbowych 52-tygodniowych od stycznia 2009 r. do czerwca 2011 r. 
Tabela 2. Relacja OCR w zbiorze $Z_{18}$ w okresie I

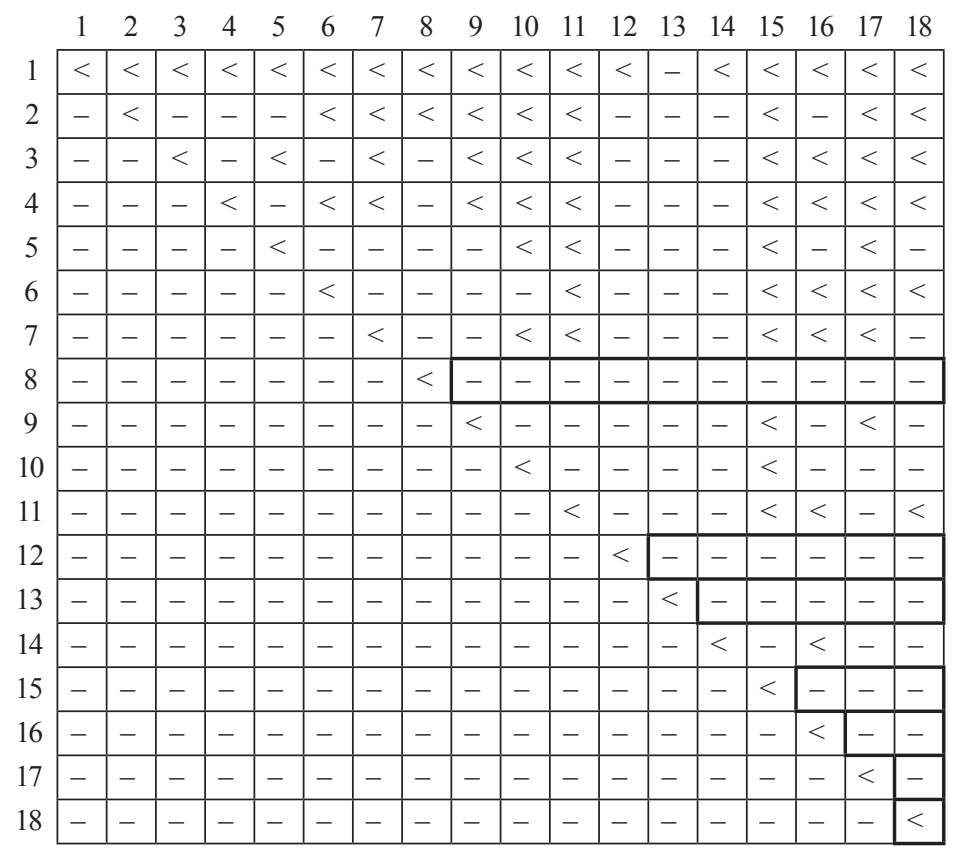

Źródło: obliczenia własne.

Tabela 3. Parametry portfeli dla zbiorów $Z_{18}$ oraz $Z_{\max }$ w wariantach KSD i KSZ

\begin{tabular}{|c|l|l|l|}
\hline Zbiór akcji & Portfel & $E r$ & $s$ \\
\hline \multirow{4}{*}{ Wszystkie inwestycje bazowe } & $P_{\min }$ & 0,1137 & 0,000003 \\
\cline { 2 - 4 } & $P$ & 0,05 & 0,0116 \\
\cline { 2 - 4 } & $P_{W S}$ & 0,0436 & 0,0998 \\
\cline { 2 - 4 } & $P^{K S Z}{ }_{\min }$ & 0,0402 & 0,0377 \\
\cline { 2 - 4 } & $P^{K S Z}$ & 0,05 & 0,0457 \\
\hline \multirow{3}{*}{ Elementy maksymalne } & $P_{\min }$ & 0,0401 & 0,0324 \\
\cline { 2 - 4 } & $P$ & 0,05 & 0,0400 \\
\cline { 2 - 4 } & $P_{W S}$ & 0,0494 & 0,0581 \\
\cline { 2 - 4 } & $P^{K S Z}{ }_{\min }$ & 0,0402 & 0,0377 \\
\cline { 2 - 4 } & $P^{K S Z}$ & 0,05 & 0,0457 \\
\hline
\end{tabular}

Źródło: obliczenia własne. 
$Z_{18}$ oraz $Z_{\max }$ na tle krzywych Markowitza w wariantach KSD i KSZ przedstawia rys. 3. Portfele $P_{\min }$ oraz $P$ są optymalne. Portfel $P_{W S}$ leży wewnątrz zbioru możliwości inwestycyjnych, więc nie ma tej własności, jednak jego położenie wskazuje, że może być również atrakcyjny dla inwestora.

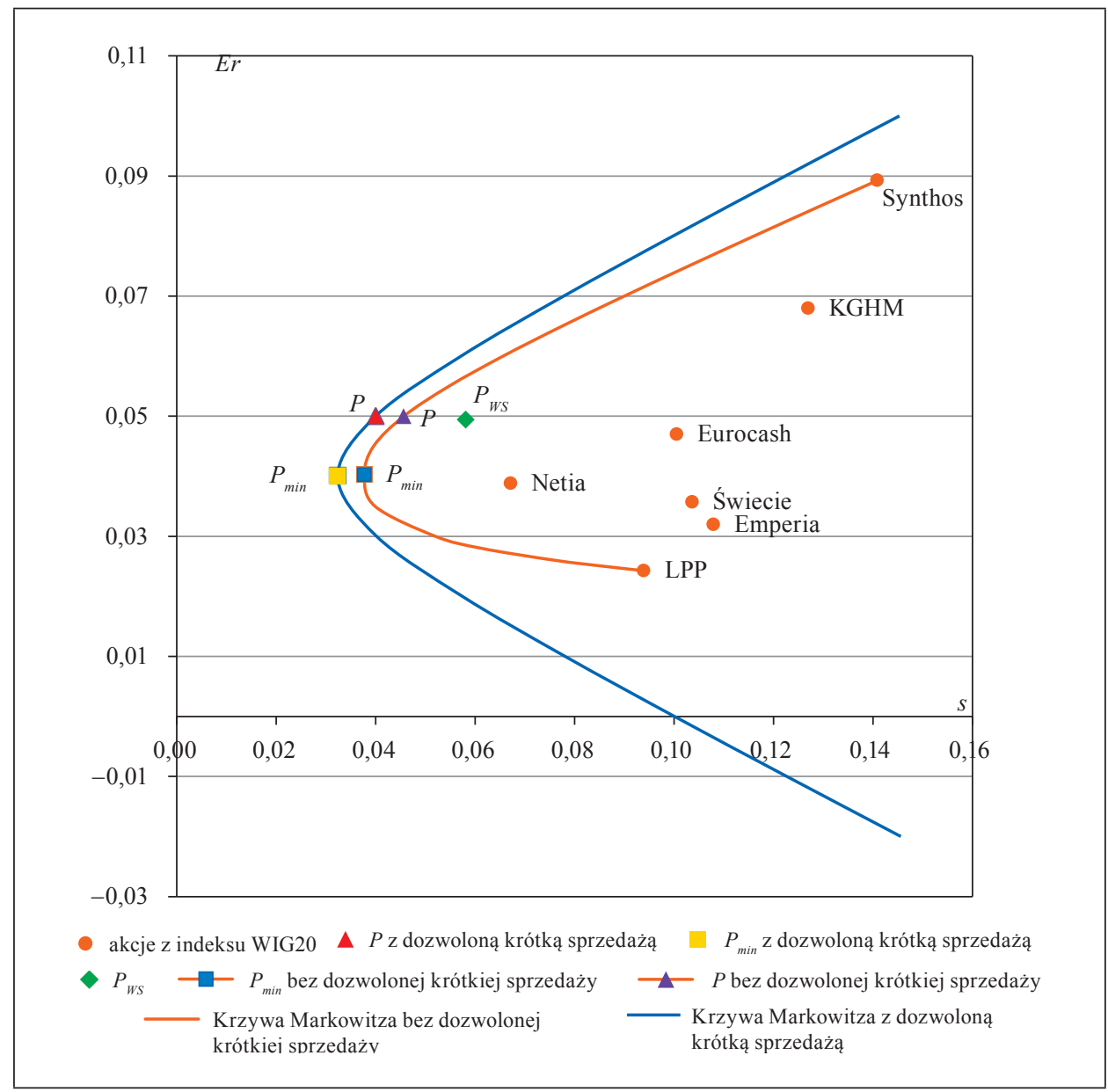

Rys. 3. Położenie portfeli na tle krzywych Markowitza w okresie I Źródło: obliczenia własne.

Obecnie porównamy rentowność portfeli w kolejnych okresach horyzontu inwestycyjnego. W tym celu za pomocą wzoru (6) ustalamy udziały inwestycji bazowych w portfelach $P_{\min }$ i $P$, a na podstawie wzoru (10) ustalamy udziały portfela $P_{W S}$. Z przeprowadzonych obliczeń wynika, że w wariancie KSZ w skład 
portfela $P_{\min }$ oraz $P$ wchodzą te same akcje, z identycznymi udziałami, niezależnie od tego czy uwzględniamy zbiór $Z_{18}$, czy tylko $Z_{\max }$. Zatem dla wyznaczenia składu tych portfeli tak naprawdę istotne były akcje, które znalazły się w zbiorze elementów maksymalnych. Analogiczną sytuację, z nielicznymi wyjątkami, obserwujemy w kolejnych okresach. W wariancie KSD takiej analogii nie ma.

Przedstawioną wyżej procedurę, zgodnie ze strategią opisaną w pkt 3, powtarzamy w kolejnych okresach. Dla przejrzystości rozważań pominięto prezentację zmieniających się charakterystyk oraz udziałów analizowanych portfeli w kolejnych okresach horyzontu inwestycyjnego.

Na rys. 4 i 5 porównano wartości zaproponowanych portfeli w kolejnych 10 okresach (miesiącach) horyzontu inwestycyjnego (wartość początkowa $=100$ ) w różnych wariantach strategii inwestycyjnej. Dla porównania na wykresach naniesiono także rentowność portfela WIG i WIG20.

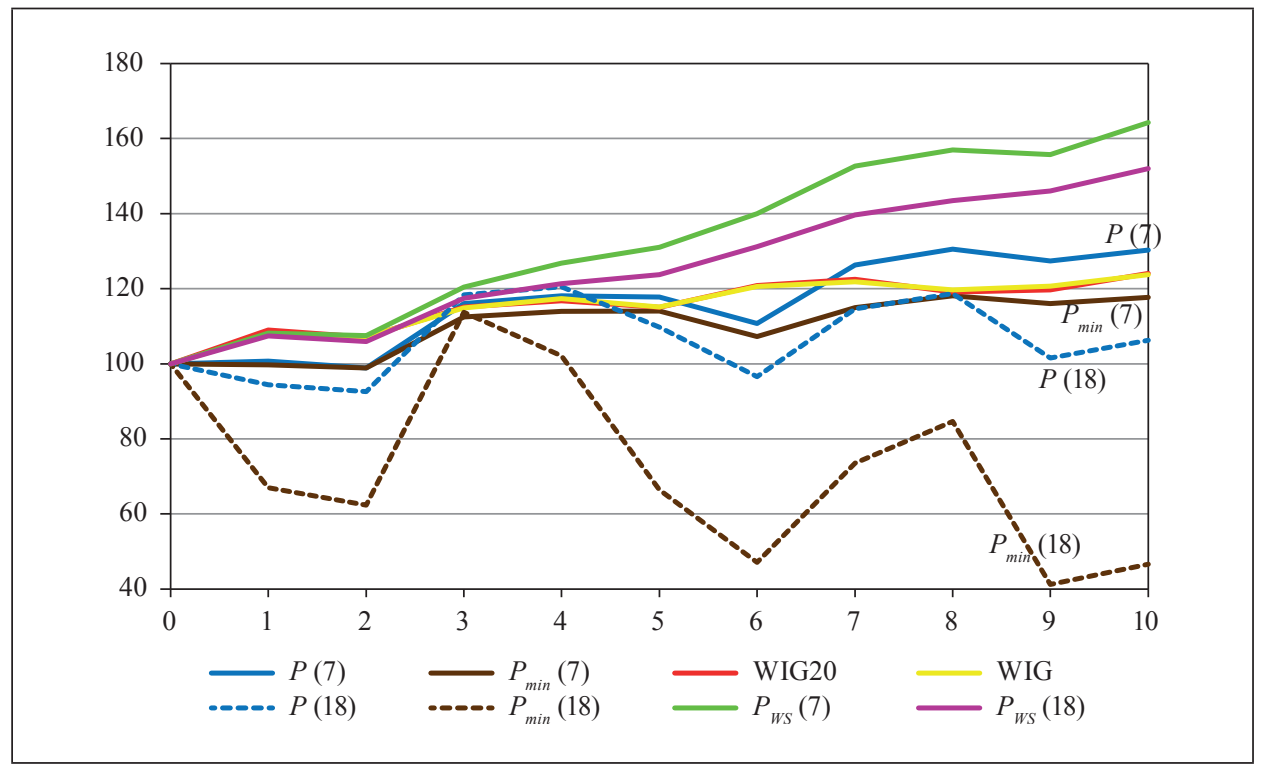

Rys. 4. Obserwacja wartości portfeli w strategii statycznej - wariant KSD Źródło: obliczenia własne.

Strategię statyczną, w której udziały poszczególnych inwestycji bazowych nie zmieniają się w kolejnych okresach, przedstawiono na rys. 4 i 5. Przyjęto oznaczenia: $P(7)$ - portfel utworzony ze zbioru $Z_{\max }, P(18)$ - portfel utworzony ze zbioru $Z_{18}$. Przeprowadzono podobną analizę wykresów dla strategii dynamicznej, w której dokonano modyfikacji udziałów poszczególnych składników 


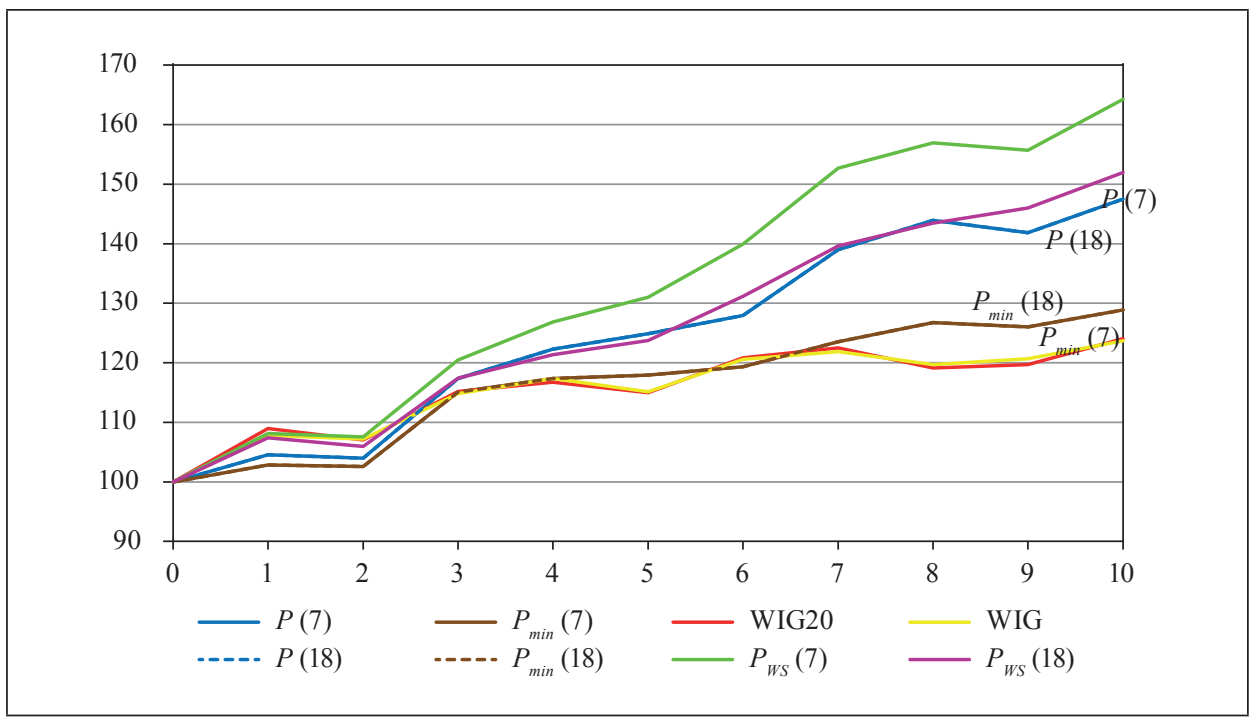

Rys. 5. Obserwacja wartości portfeli w strategii statycznej - wariant KSZ Źródło: obliczenia własne.

zgodnie z nową prognozą charakterystyk portfeli. W podsumowaniu artykułu zostały omówione wyniki tej analizy.

\section{Podsumowanie}

W artykule przedstawiono porównanie efektywności inwestycji w portfele inwestycyjne w warunkach dozwolonej (KSD) i zabronionej (KSZ) krótkiej sprzedaży przy wprowadzonej relacji częściowego porządku OCR w zadanym zbiorze akcji $Z_{18}$, wyznaczającej zbiór elementów maksymalnych $Z_{\max }$. W tych zbiorach analizowano trzy rodzaje portfeli $P_{m i n}, P$ i $P_{W S}$, przy czym pierwsze dwa należą do granicy efektywnej.

Ponieważ elementy zbioru $Z_{\max }$ leżą blisko granicy efektywnej utworzonej z elementów zbioru $Z_{18}$, to parametry portfeli $P_{\text {min }}, P$ wyznaczone w tych zbiorach nie powinny się od siebie różnić. Badania empiryczne potwierdzają te przewidywania w wariancie KSZ dla okresu I (tabela 3 i rys. 3) jak i pozostałych okresów. Ograniczenie inwestycji bazowych do zbioru $Z_{\max }$ nie pogarsza parametrów konstruowanych portfeli z granicy efektywnej, a mniejsza (średnio o 40-50\%) liczba akcji w portfelu ułatwia jego zarządzanie.

W wariancie KSD różnice między parametrami (wartościami oczekiwanymi) portfeli $P_{\min }, P$ wyznaczonych dla zbiorów $Z_{18}$ i $Z_{\max }$ są znaczne (tabela 3 ). 
Analizę strategii inwestycyjnych zaczniemy od stwierdzenia, że wartość indeksów WIG i WIG20 oraz każdego portfela (z wyjątkiem $P_{\min }$, w wariancie KSD dla $Z_{18}$ ) na koniec horyzontu inwestycyjnego wzrosła, podobnie jak w kolejnych jego okresach.

Niezależnie od strategii i wariantu krótkiej sprzedaży (KS), w zdecydowanej większości okresów horyzontu inwestycyjnego portfele zbudowane na bazie $Z_{\max }$ miały wyższą stopę zwrotu niż zbudowane ze zbioru $Z_{18}$. Zauważamy, że portfele $P_{\min }$ oraz $P$ w wariancie $\mathrm{KSZ}$ w kolejnych okresach były prawie identyczne, a na ich tle rentowność portfela $P_{W S}$ była wysoka.

Portfel $P_{\min }$ (ze zbioru $Z_{\max }$, wariant KSD, strategia statyczna) był również gorszy od indeksów giełdowych (brakiem reakcji na zmieniające się parametry portfeli). W strategii dynamicznej począwszy od 4 okresu (z jednym wyjątkiem) wszystkie portfele mają wartość wyższą niż indeksy giełdowe. Na koniec horyzontu inwestycyjnego wartość portfeli ze zbioru $Z_{\max }$ wyniosła od ok. 125 do 170 i była wyższa od wartości indeksów giełdowych. Lepsze wyniki uzyskano w strategii dynamicznej.

Przeprowadzone badania wskazują, że zbudowane portfele inwestycyjne złożone z elementów maksymalnych relacji OCR przewyższały rentownością portfele zbudowane ze wszystkich aktywów jak również indeksy giełdowe. Wniosek ten wymaga potwierdzenia na szerszym zbiorze akcji i dłuższym horyzoncie czasowym.

\section{Literatura}

Guzik K. [2002], Relacja ograniczonej ceny ryzyka w modelowaniu rynku kapitałowego, Akademia Ekonomiczna w Krakowie, Kraków (praca doktorska niepublikowana).

Guzik K., Smaga E. [2008], Istotność składników portfela, „Zeszyty Naukowe Uniwersytetu Ekonomicznego w Krakowie" nr 780.

Guzik K., Smaga E. [2013], Ryzyko i rentowność inwestycji finansowych i rzeczowych, Wydawnictwo Uniwersytetu Ekonomicznego w Krakowie, Kraków.

Hull J.C. [2011], Zarzadzanie ryzykiem instytucji finansowych, Wydawnictwa Profesjonalne PWN, Warszawa.

Jajuga K., Jajuga T. [1998], Inwestycje: instrumenty finansowe, ryzyko finansowe, inżynieria finansowa, $\mathrm{PWN}$, Warszawa.

Jajuga K. [2007], Zarzadzanie ryzykiem, Wydawnictwo Naukowe PWN, Warszawa.

Luenberger D.G. [2003], Teoria inwestycji finansowych, Wydawnictwo Naukowe PWN, Warszawa.

Markowitz H. [1959], Portfolio Selection: Efficient Diversification of Investments, „Journal of Financial and Quantitative Analysis", vol. 7 (4).

Piasecki K. [2005], Od arytmetyki handlowej do inżynierii finansowej, Wydawnictwo Akademii Ekonomicznej w Poznaniu, Poznań. 


\section{Profitability of Investment Portfolios Based on Partial Order Relations}

The article compares the effectiveness of investing in portfolios which use reduced risk relationship prices under short sale and forbidden short sale. This risk relationship in a given set of shares determined a partial order consistent with the Sharpe ratio. In the chain of relationships, the reduced risk relationship maximal element is the most effective one.

The obtained maximal elements-created portfolios were: $P_{\min }$ (a minimum risk portfolio), $P$ (efficient portfolio with a $5 \%$ rate of return) and portfolio $P_{W S}$ (a portfolio based on Sharpe ratio). These portfolios were compared with those formed from all of the shares using the same rules as portfolios $P, P_{\min }, P_{W S}$. In consecutive periods of a fixed investment horizon it was found that the profitability of portfolios created from the maximal elements exceeded that of the portfolios formed from all the shares.

Keywords: Markowitz curve, efficient portfolio, investment strategy, short sale, the maximal elements of partial order relations. 